\title{
Is Drinking to Thirst Optimum?
}

\author{
Timothy David Noakes \\ Department of Human Biology, University of Cape Town, Sports Science Institute of South Africa, \\ Newlands, South Africa
}

\section{Key Words}

Fluids - Exercise - Dehydration - Overhydration - Thirst •

Marathon $\cdot$ Drinking guidelines

\begin{abstract}
Backgrounds/Aims: Prior to 1969, athletes were advised to avoid drinking during exercise. At least 4 subsequent events led to the adoption of a radically different approach. By 1996, all exercisers were advised to drink 'as much as tolerable' in order to insure that they did not lose any weight during exercise - the 'zero percent dehydration' doctrine. This advice requires that athletes drink enough to 'stay ahead of thirst'. The act of drinking is a basic survival instinct that has been regulated by complex, unconscious controls ever since the first fish-like creatures moved onto land and should not require conscious adjustment. Methods: Literature survey of all studies comparing the effects of drinking to thirst (ad libitum) and drinking to prevent any weight loss during exercise - the 'zero percent dehydration' doctrine. Result: No study found that drinking more than ad libitum during exercise produced any biological advantage, but it could cause exercise-associated hyponatremia. Conclusion: Drinking ad libitum appears to optimize performance and safety during exercise in many situations. The presence of thirst, not of wa-
\end{abstract}

ter loss, may be the biological signal that impairs exercise performance in those who drink less than their thirst dictates during exercise.

Copyright $\odot 2011$ S. Karger AG, Basel

\section{Introduction}

The idea that athletes should not drink anything at all during exercise, especially marathon running, is of quite recent origin. Thus American Joseph Forshaw, who finished fourth in the 1908 Olympic Marathon and tenth in the 1912 Olympic Marathon, wrote: 'I know from actual experience that the full race can be covered in creditable time without so much as a single drop of water being taken or even sponging of the head'. Similar advice was given to marathon runners of the early 1900s: 'Don't get into the habit of drinking and eating in a marathon race; some prominent runners do, but it is not beneficial' [1].

As recently as 1957, Englishman Jim Peters, who set the world marathon record on 4 occasions and who may have been the greatest marathoner of all time, expressed a similar belief: '[In the marathon race] there is no need to take any solid food at all and every effort should also be made to do without liquid, as the moment food or 
drink is taken, the body has to start dealing with its digestion, and in so doing some discomfort will almost invariably be felt' [1].

But today's athletes are bombarded daily with a quite different message. They are advised that only if they stay 'ahead of thirst' by drinking copiously to prevent 'dehydration' before, during and after competition will they perform optimally in any competitive sport [2-6]. Worse, if they do not follow this advice, they risk their health, perhaps their lives.

But which message is correct? Should athletes drink nothing, or should they drink to 'stay ahead of thirst'? Or should they perhaps drink according to endogenous biological signals, in particular to the dictates of thirst as do all the rest of earth's creatures? Since this has become a debate charged with an unusual level of emotion [7], it is instructive to understand how ideas in this field have been influenced by a series of phenomena which occurred between 1965 and 1996 and which produced this diametric change in the popular drinking advice for athletes.

\section{The Development of the World's Second 'Sports Drink' by Dr. Robert Cade at the University of Florida in 1965}

The world's first sports drink was developed in South Africa in 1924 by the ultramarathon runner and multiworld record holder, Arthur Newton [8]. The laconic Newton called his innovation the Corpse Reviver and advised that it was most effective in running races longer than $42 \mathrm{~km}$.

Forty-one years later, in 1965, the world's second sports drink was developed by a renal physician, Dr. Robert Cade, at the University of Florida. Prior to the development of his drink, subsequently known as Gatorade, US football players were discouraged from drinking during either practices or matches. But Dr. Cade grew to believe that the ingestion of his custom-designed sports drink would improve football performances (especially in the fourth quarter) and would eliminate heat stroke. His simple studies at the time [9, 10] did not show that fluid ingestion was necessary to prevent heat stroke during exercise. However, the ingestion of the carbohydrate-containing solution clearly improved performance in a 7-mile run/walk [9], at that time a novel finding.

\section{The Landmark Scientific Study Reported by Two South African Exercise Physiologists, Drs. Cyril Wyndham and Nick Strydom in 1969}

The second influential factor was a landmark scientific study undertaken by 2 South African physiologists in 1969. They studied runners in $32-\mathrm{km}$ road races and concluded that the body temperatures of athletes who became dehydrated by more than $3 \%$ of their prerace body weights (BWs) were elevated to levels that the authors considered unacceptable [11]. They proposed incorrectly (since the study was of a cross-sectional design and cannot therefore prove causation) that a $>3 \%$ loss of BW during exercise is detrimental because it causes the body temperature to rise excessively. They concluded that higher BW losses during exercise must inevitably cause heat stroke.

Despite the logical errors that it contained, that 1969 study was of great practical significance, for it drew attention to the illogic of the International Amateur Athletic Federation's Rule No. 165.5, which stipulated that marathon runners could drink no fluids before the $11-\mathrm{km}$ mark of a $42-\mathrm{km}$ marathon and thereafter could drink only every $5 \mathrm{~km}$. This ruling altered the 1953 International Amateur Athletic Federation rule which stated that 'refreshments shall (only) be provided by the organizers after $15 \mathrm{~km}$. No refreshments may be carried or taken by a competitor other than that provided by the organizers'. These early rulings discouraged marathon runners from drinking during races and promoted the idea that drinking was unnecessary and a sign of 'weakness'.

From the results of their original study, Wyndham and Strydom concluded that marathon runners should aim to drink $250 \mathrm{ml}$ of fluid every $15 \mathrm{~min}$ during exercise $(1,000 \mathrm{ml} / \mathrm{h})$. This value closely matched the athletes' average sweat rates during that race (run in relatively cool conditions). Thus these authors were proposing that athletes should drink to stay 'ahead of thirst' to insure that they did not lose more than 3\% BW during exercise.

The basis for this conclusion was their apparent finding that only a $>3 \% \mathrm{BW}$ loss (about $2 \mathrm{~kg}$, equivalent to 2 liters of body water/sweat) was associated with an excessive rise in rectal temperature. But had Wyndham and Strydom concluded that about 2 liters of fluid can be lost without incurring a physiological penalty, as originally proposed by Ladell [12] during the Second World War, their suggested rates of fluid intake would have been closer to $500 \mathrm{ml} / \mathrm{h}$. This is the rate of fluid intake that athletes typically adopt when encouraged to drink according to the dictates of their thirst [13], that is, ad libitum. 
The US Military Adopts the 'Water as a Tactical Weapon' Doctrine with Global Consequences

The third important event was the adoption of the 'Water as a Tactical Weapon' doctrine by the United States Military after 1982 [14]. According to this logic, US Military forces would gain a tactical advantage if they followed a strategy that combined very high rates of fluid ingestion (up to $1.8 \mathrm{l} / \mathrm{h}$ ) with periods of alternating activity and rest in battles fought in hot environments. This doctrine developed by staff of the United States Army Research Institute for Environmental Medicine (USARIEM) was soon adopted by the US Military [15]. A study supposedly proving the efficacy of this intervention was subsequently published [14]. But that study is flawed since subjects were not properly randomized to different groups at the start of the trial. Nor is there evidence that the subjects in the intervention trial actually drank more than did those in the control group or that they suffered fewer cases of 'heat illness' since the outcome measures on which the conclusions were drawn were not properly included in the published data. Thus the study does not allow any definitive conclusions. The consequence was that a novel but unproven doctrine, acquired as if by divine inspiration, soon became the global mantra.

This new doctrine spread rapidly beyond the confines of the US Military as USARIEM-trained scientists became the principal advisors to influential bodies like the American College of Sports Medicine (ACSM). Thus whereas the 1975 [16] and 1987 [2] ACSM position stands on the prevention of thermal injuries during distance running were published anonymously, this practice was abandoned for the $1996[3,4]$ and $2007[5,6]$ guidelines. This revealed that all the senior authors of the 4 ACSM position stands published in 1996 and 2007 were either trained at or are currently employed by the USARIEM or the US Army. The originator of the 'Water as a Tactical Weapon' doctrine, USARIEM employee Dr. Roger Hubbard, $\mathrm{PhD}$ [14], also contributed to the 1996 position stands.

\section{The Involvement of the Sports Drink Industry}

The fourth development was the growing involvement of industry with scientists studying fluid balance during exercise. While the natural presumption is that such relationships benefit everyone, the reality is that industry's involvement can come at a price [17], for the law in the United States requires that a company that is publicly list- ed must show a return on its investment for any monies granted 'altruistically'. This ruling flows from the landmark case of Dodge versus the Ford Motor Company heard in the Michigan Supreme Court in 1919 [18].

The necessary return for the US sports drink industry was the massive growth in annual turnover from USD 217 million in 1985 to USD 2.69 billion in 2003. This growth in sales occurred at precisely the time that athletes were being advised by the US Military and the ACSM to change their drinking behaviors from avoiding drinking (up to 1969) to drinking 'as much as tolerable' during exercise (1987 to 2007).

\section{Common Features of the Drinking Guidelines Developed between 1987 and 2007}

The most influential drinking guidelines were developed by the ACSM between 1987 and 2007. These were grounded on the novel USARIEM 'Water as a Tactical Weapon' doctrine and developed 5 core doctrines [19].

First, the 1996 ACSM position stands [3, 4] proposed that all the weight lost during exercise must be replaced if health is to be protected and performance is to be optimized. I have termed this the 'zero percent dehydration' rule. The commercial value of this ruling is obvious for it requires that all exercisers begin drinking 'as much as tolerable' the instant they start any exercise regardless of its duration or intensity. One consequence of this advice may have been the development of a global increase in cases of exercise-associated hyponatremia (EAH) and its associated encephalopathy (EAHE) $[20,21]$. This forced the publication of the revised 2007 ACSM position stand which now advises exercisers to avoid overdrinking and instead to drink to thirst but sufficient to insure that they do not lose $>2 \%$ of their starting BW during any form of exercise.

Second, fluid ingestion alone can minimize the risk of serious exercise-related heat illness regardless of the circumstances in which exercise is undertaken.

Third, the sensations of thirst in humans underestimate real fluid requirements before, during and after exercise. As a result, unless properly informed, human athletes will always drink too little, before, during and after exercise.

Fourth, the fluid requirements of all athletes, big and small, fast and slow, are sufficiently similar that a single universal guideline is possible for all exercisers during all forms of exercise in all environmental conditions. 
However, none of these ideas is evidence-based [19, $22,23]$; that is, none is based on properly conducted, peer-reviewed, scientific evidence that unequivocally proves these conclusions and excludes all other possible interpretations. In particular, it has never been shown that athletes who drink ad libitum and who therefore develop mild levels of dehydration during competitive sport are at an increased risk of avoidable health consequences. Nor is it certain that all the weight lost during exercise must be replaced immediately. Rather it appears that, as originally proposed by Ladell [12] in the 1940s, there may be a 1- to 2-liter fluid reserve [24-28] within the body that may not require immediate replacement during exercise.

There is no evidence that athletes perform better during out-of-doors competition if they drink at the very high rates proposed by both the 1996 and 2007 ACSM position stands or the US Army guidelines after 1984 [23]. Nor does it seem likely that fluid ingestion alone will prevent serious heat illness in those conditions in which heatstroke is most likely to occur, namely competitive exercise of short duration but high intensity in severe environmental conditions and in which significant levels of dehydration do not occur. Furthermore, sustained high rates $(1,200-1,800 \mathrm{ml} / \mathrm{h})$ of fluid ingestion either at rest or during exercise are neither sustainable by elite athletes nor safe for recreational athletes since they produce symptoms of intestinal distress $[29,30]$ including nausea, vomiting and on occasion, diarrhea, or progressive fluid overload leading ultimately to death from EAHE as has now been reported in at least 12 athletes. In contrast, this author has been unable to track a single published report in the past 20 years of exercise-related death or serious illness due solely to 'dehydration'.

\section{Evidence that Drinking to Thirst Is the Optimum Method of Fluid Replacement during Exercise}

The adoption by the US Military of the "Water as a Tactical Weapon' doctrine was the singular factor that led to the altered global drinking patterns during exercise from drinking nothing at all to drinking 'as much as tolerable'. But this change was not evidence-based.

The proper experiments to justify this radical change would have compared the effects of this new advice to what was then the accepted practice - drinking either nothing or ad libitum. Since this essential scientific step was shirked, a critical gap in the scientific literature has developed. Thus there are very few published scientific studies which properly compare the novel drinking approach - 'drinking to stay ahead of thirst' - to drinking according to the normal human biological controls, that is according to the dictates of thirst (ad libitum).

Table 1 includes a range of studies in which the effects of ad libitum drinking have been investigated in subjects performing exercise either in the laboratory or out of doors. Performance was not measured in all these studies. But in none of those studies in which performance was properly measured in the laboratory was full fluid replacement superior to ad libitum drinking.

The studies of Daries et al. [31] and Dugas et al. [32] are particularly relevant. In the former study, ad libitum drinking compared to full fluid replacement was associated with superior performance during a 30-min running time trial but small numbers mitigated against a significant finding. Dugas et al. [32] performed the most complete study yet reported. They compared the effects on performance during an $80-\mathrm{km}$ (non-weight-bearing) cycling time trial in subjects who followed 6 different fluid replacement regimes on separate occasions: (1) no fluid; (2) mouth washing without fluid ingestion; (3) replacing 33\% of fluid losses; (4) ad libitum drinking (replacing approximately $55 \%$ of fluid losses); (5) replacing $66 \%$ of fluid losses; (6) replacing $100 \%$ of fluid losses. Analysis showed that there was no significant advantage of drinking more than ad libitum. However, drinking less than ad libitum was associated with a $2 \%$ impairment of performance compared to drinking ad libitum or more.

In a series of studies performed in athletes in competition, it has been found that ad libitum drinking maintains physiological markers of hydration status [33, 34], including the total body water $[24-28,34,35]$, within the normal range or conversely that those athletes who lose the most weight are usually the most successful finishers [36-41].

The finding that 'ad libitum' or 'some' fluid ingestion during exercise appears to be at least as good as [32] or perhaps even better than 'drinking as much as tolerable' [30] has one important intellectual consequence, for it suggests that it is not the level of dehydration that determines the extent to which performance is affected by either fluid ingestion or its avoidance during exercise. Rather it may be that performance will be optimized regardless of the degree of dehydration that develops, provided that sufficient fluid is ingested during exercise to prevent the development of thirst [42]. In other words, it is the development of thirst that is associated with the impairment of performance, not the ex- 
Table 1. Effects on ad libitum drinking on physiological variables during exercise

\begin{tabular}{|c|c|c|c|c|c|c|c|}
\hline Study & $\begin{array}{l}\text { Sam- } \\
\text { ple } \\
\text { size } \\
\text { n }\end{array}$ & & $\begin{array}{l}\text { Environ- } \\
\text { ment, }{ }^{\circ} \mathrm{C} \text {; } \\
\text { RH, \%; } \\
\text { WS, kph }\end{array}$ & $\begin{array}{l}\text { Drink } \\
\text { conditions }\end{array}$ & $\begin{array}{l}\text { Dehydra- } \\
\text { tion, BW loss }\end{array}$ & Performance results & My conclusions \\
\hline $\begin{array}{l}\text { Below } \\
\text { et al. [49] }\end{array}$ & 8 & $\begin{array}{l}\mathrm{CE} \text { at } 50 \% \mathrm{VO}_{2} \max \\
\text { for } 50 \mathrm{~min} \text {, then } \mathrm{PR}\end{array}$ & $31 ; 54$ & $\begin{array}{l}\text { LF } \\
\text { FF }\end{array}$ & $\begin{array}{l}\mathrm{LF}=2.0 \% \\
\mathrm{FF}=0.5 \%\end{array}$ & $\mathrm{LF}=7 \%$ decrease in $\mathrm{PR}$ & $\begin{array}{l}\text { Less than ad libitum drinking } \\
\text { impairs exercise performance }\end{array}$ \\
\hline $\begin{array}{l}\text { McConell } \\
\text { et al. [50] }\end{array}$ & 7 & $\begin{array}{l}\mathrm{CE} \text { at } 69 \% \mathrm{VO}_{2} \max \\
\text { for } 120 \mathrm{~min} \text {, then } \\
90 \% \mathrm{VO}_{2} \max \text { to } \\
\text { exhaustion in the } \\
\text { laboratory }\end{array}$ & 21 & $\begin{array}{l}\text { NF } \\
\text { SF } \\
\text { FF }\end{array}$ & $\begin{array}{l}\mathrm{NF}=3.2 \% \\
\mathrm{SF}=1.8 \% \\
\mathrm{FF}=0.1 \%\end{array}$ & $\begin{array}{l}\mathrm{NF}=48 \% \text { decrease in PR vs. FF } \\
\text { No difference in PR between SF } \\
\text { and FF }\end{array}$ & $\begin{array}{l}\text { No additional benefit of } \\
\text { drinking more than 'some' } \\
\text { fluid }\end{array}$ \\
\hline $\begin{array}{l}\text { McConell } \\
\text { et al. [51] }\end{array}$ & 8 & $\begin{array}{l}\mathrm{CE} \text { at } 80 \% \mathrm{VO}_{2} \max \\
\text { for } 45 \mathrm{~min} \text {, then } 15 \\
\text { min } \mathrm{PR} \text { in the } \\
\text { laboratory }\end{array}$ & $21 ; 41$ & $\begin{array}{l}\text { NF } \\
\text { SF } \\
\text { FF }\end{array}$ & $\begin{array}{l}\mathrm{NF}=1.9 \% \\
\mathrm{SF}=1.0 \% \\
\mathrm{FF}=0.0 \%\end{array}$ & $\begin{array}{l}\text { No differences in PR among } \\
\text { trials }\end{array}$ & $\begin{array}{l}\text { No benefit of any volume of } \\
\text { fluid ingestion on } \\
\text { performance during exercise } \\
\text { of approx. } 60 \mathrm{~min}\end{array}$ \\
\hline $\begin{array}{l}\text { Daries } \\
\text { et al. [31] }\end{array}$ & 8 & $\begin{array}{l}\mathrm{TM} \text { at } 65 \% \mathrm{VO}_{2} \mathrm{max} \\
\text { then 'as far as } \\
\text { possible' in } 30 \mathrm{~min}\end{array}$ & $25 ; 55$ & $\begin{array}{l}\text { AL } \\
\text { SF } \\
\text { FF }\end{array}$ & $\begin{array}{l}\mathrm{AL}=1.95 \% \\
\mathrm{SF}=1.59 \% \\
\mathrm{FF}=0.75 \%\end{array}$ & $\begin{array}{l}\mathrm{AL}=15.8 \mathrm{kph} \text { for } 30 \mathrm{~min} \\
\mathrm{SF}=15.6 \mathrm{kph} \text { for } 30 \mathrm{~min} \\
\mathrm{FF}=15.4 \mathrm{kph} \text { for } 30 \mathrm{~min}\end{array}$ & $\begin{array}{l}\text { Ad libitum drinking produced } \\
\text { insignificantly faster } \\
\text { performance in the } 30 \text { min PR } \\
\text { than did either 'some' or 'full } \\
\text { fluid' replacement }\end{array}$ \\
\hline $\begin{array}{l}\text { Backx } \\
\text { et al. [52] }\end{array}$ & 8 & CE time trial & $20 ; 70$ & $\begin{array}{l}\text { LF } \\
\text { MF } \\
\text { AL } \\
\text { FF }\end{array}$ & $\begin{array}{l}\mathrm{LF}=1.25 \% \\
\mathrm{MF}=1.0 \% \\
\mathrm{AL}=0.7 \% \\
\mathrm{FF}=0.5 \%\end{array}$ & $\begin{array}{l}\text { No differences in PR among } \\
\text { trials }\end{array}$ & $\begin{array}{l}\text { No benefit of drinking more } \\
\text { than 'little' fluid during } \\
\text { exercise }\end{array}$ \\
\hline $\begin{array}{l}\text { Sharwood } \\
\text { et al. [38] }\end{array}$ & 736 & $\begin{array}{l}\text { South African } \\
\text { Ironman Triathlon }\end{array}$ & $\begin{array}{l}17.2-20.5 \\
55-63 \\
\text { WS } 15-23\end{array}$ & $\mathrm{AL}$ & $\begin{array}{l}\text { Ranged from } \\
12 \% \text { (loss) to } \\
+1 \% \text { (gain) }\end{array}$ & $\begin{array}{l}\text { No relationship between } \% \mathrm{BW} \\
\text { loss and either post-race rectal } \\
\text { temperature or performance }\end{array}$ & $\begin{array}{l}\text { No apparent effect of weight } \\
\text { losses up to } 12 \% \text { on } \\
\text { performance or body } \\
\text { temperature }\end{array}$ \\
\hline $\begin{array}{l}\text { Saunders } \\
\text { et al. [53] }\end{array}$ & 9 & $\begin{array}{l}120 \text { min exercise at } \\
182 \mathrm{~W}\end{array}$ & $\begin{array}{l}33 ; 59 ; \\
\text { WS } 33\end{array}$ & $\begin{array}{l}59(\mathrm{AL}) \text { and } \\
80 \%(\mathrm{FF}) \\
\text { of BW loss }\end{array}$ & $\begin{array}{l}\mathrm{AL}=1.7 \% \\
\mathrm{FF}=0.7 \%\end{array}$ & $\begin{array}{l}\text { No additional effect of the } \\
\text { higher rate of fluid ingestion on } \\
\text { heat storage, sweat rate, body } \\
\text { temperature or rectal } \\
\text { temperature }\end{array}$ & $\begin{array}{l}\text { No additional benefit of } \\
\text { replacing more than } 59 \% \text { of } \\
\text { BW losses (AL) during } \\
\text { exercise when convective heat } \\
\text { losses matched those present } \\
\text { in out-of-doors exercise }\end{array}$ \\
\hline $\begin{array}{l}\text { Fudge } \\
\text { et al. [54] }\end{array}$ & 14 & $\begin{array}{l}\text { Daily training over } \\
5 \text { days }\end{array}$ & $\begin{array}{l}8-24 \\
31-100\end{array}$ & $\mathrm{AL}$ & $0.8-2.7 \%$ & $\begin{array}{l}\text { Early morning TBW and body } \\
\text { mass was unchanged during } \\
\text { training. Evening and early } \\
\text { morning urine osmolality did } \\
\text { not indicate the presence of } \\
\text { 'dehydration' }\end{array}$ & $\begin{array}{l}\text { Habitual AL fluid intake 'was } \\
\text { adequate to maintain } \\
\text { hydration and electrolyte } \\
\text { balance on a daily basis in } \\
\text { elite Kenyan endurance } \\
\text { runners' (p. 1178) }\end{array}$ \\
\hline $\begin{array}{l}\text { Kao } \\
\text { et al. [37] }\end{array}$ & 41 & $\begin{array}{l}12 \text { - or 24-hour track } \\
\text { races }\end{array}$ & $\begin{array}{l}11.5-14.6 \\
55-65 \\
\text { WS } 9-18\end{array}$ & $\mathrm{AL}$ & $0-11.4 \%$ & $\begin{array}{l}\text { Better performance occurred in } \\
\text { those who lost the most weight }\end{array}$ & $\begin{array}{l}\text { No evidence that the } \\
\text { prevention of weight loss by } \\
\text { drinking more than ad libitum } \\
\text { enhanced performance. } \\
\text { Rather those who lost the } \\
\text { most weight performed the } \\
\text { best }\end{array}$ \\
\hline $\begin{array}{l}\text { Dugas } \\
\text { et al. [32] }\end{array}$ & 6 & $\begin{array}{l}80 \mathrm{~km} \text { self-paced } \\
\text { CE time trial }\end{array}$ & $33 ; 50$ & $\begin{array}{l}\text { NF } \\
\text { MR } \\
\text { Less than AL } \\
\text { AL } \\
\text { SF } \\
\text { FF }\end{array}$ & $\begin{array}{l}\mathrm{NF}=4.3 \% \\
\mathrm{MR}=3.9 \\
\text { Less than } \mathrm{AL}=2.9 \% \\
\mathrm{AL}=2.1 \% \\
\mathrm{SF}=1.9 \% \\
\mathrm{FF}=0.5 \%\end{array}$ & $\begin{array}{l}\text { Less than AL (including MR) = } \\
2 \% \text { decrease in PR. No } \\
\text { difference in performance } \\
\text { between AL, SF or FF }\end{array}$ & $\begin{array}{l}\text { No benefit of drinking more } \\
\text { than ad libitum during } \\
\text { exercise. No effect of the } \\
\text { volume of fluid ingestion on } \\
\text { the rectal temperature at the } \\
\text { termination of exercise }\end{array}$ \\
\hline $\begin{array}{l}\text { Zouhal } \\
\text { et al. [40] }\end{array}$ & 16 & $\begin{array}{l}\text { 7-day (stage) } \\
\text { Marathon of Sands }\end{array}$ & $20-30$ & $\mathrm{AL}$ & $4-6 \%$ & $\begin{array}{l}\text { Plasma volume did not change } \\
\text { during the race. Athletes who } \\
\text { lost the most weight finished in } \\
\text { the shortest time }\end{array}$ & $\begin{array}{l}\text { No apparent effect of a weight } \\
\text { loss greater than } 3-6 \% \text { on } \\
\text { endurance performance }\end{array}$ \\
\hline
\end{tabular}


Table 1 (continued)

\begin{tabular}{|c|c|c|c|c|c|c|}
\hline Study & $\begin{array}{l}\text { Sam- Exercise } \\
\text { ple } \\
\text { size } \\
\mathrm{n}\end{array}$ & $\begin{array}{l}\text { Environ- } \\
\text { ment, }{ }^{\circ} \mathrm{C} \text {; } \\
\text { RH, \%; } \\
\text { WS, kph }\end{array}$ & $\begin{array}{l}\text { Drink } \\
\text { conditions }\end{array}$ & $\begin{array}{l}\text { Dehydra- } \\
\text { tion, BW loss }\end{array}$ & Performance results & My conclusions \\
\hline
\end{tabular}

Rose et al. [33]
18 3-day (stage) mountain cycling race
$6-21.4 ; 43-\mathrm{AL} \quad 0.8-1.5 \%$ 100
Serum osmolality, serum sodium concentrations and urine specific gravity remained within the normal range for the duration of the race

\begin{tabular}{|c|c|c|c|c|c|c|}
\hline $\begin{array}{l}\text { Schenk } \\
\text { et al. [34] }\end{array}$ & 25 & $\begin{array}{l}\text { 8-day (mountain) } \\
\text { cycling race }\end{array}$ & $2-32$ & $\mathrm{AL}$ & $0.2-3.6 \%$ & $\begin{array}{l}\text { ECW increased despite BW loss. } \\
\text { Almost all }(95 \%) \text { serum sodium } \\
\text { concentrations were within the } \\
\text { normal range }\end{array}$ \\
\hline
\end{tabular}

\begin{tabular}{llll}
\hline $\begin{array}{l}\text { Nolte } \\
\text { et al. [25] }\end{array}$ & 15 & $\begin{array}{l}\text { 16.4-km route } \\
\text { march }\end{array}$ & $\begin{array}{l}24.5 \mathrm{WBGT} ; \mathrm{AL} \\
57\end{array}$
\end{tabular}

\begin{tabular}{|c|c|c|c|}
\hline $\begin{array}{l}\text { Zouhal } \\
\text { et al. [41] }\end{array}$ & 643 & $\begin{array}{l}42-\mathrm{km} \text { marathon } \\
\text { race }\end{array}$ & $9-16 ; 60-82 \mathrm{AL}$ \\
\hline
\end{tabular}

\%

Euhydration was maintained by AL drinking

Euhydration was maintained by AL drinking

Euhydration (unchanged TBW) was maintained by $\mathrm{AL}$ drinking despite a 1-kg (1.4\%) BW loss Core body temperatures were not abnormally elevated after exercise

\begin{tabular}{llll}
\hline $\begin{array}{l}\text { Nolte } \\
\text { et al. [26] }\end{array}$ & 18 14.6 km & 14.1 WBGT AL & $1.3 \%$
\end{tabular}

\begin{tabular}{|c|c|c|c|c|c|c|c|}
\hline $\begin{array}{l}\text { Tam } \\
\text { et al. [27] }\end{array}$ & 9 & $80 \mathrm{~km}$ & $8-20$ & $\mathrm{AL}$ & $3.7 \mathrm{~kg}$ & $\begin{array}{l}\text { No change in plasma sodium or } \\
\text { potassium concentrations or } \\
\text { plasma osmolality despite a } 3.7 \text { - } \\
\text { kg BW loss }\end{array}$ & $\begin{array}{l}\text { Change in TBW }(0.8 \mathrm{~kg}) \text { was } \\
\text { less than the BW change }(3.7 \\
\mathrm{kg})\end{array}$ \\
\hline
\end{tabular}

\begin{tabular}{llllll}
\hline Tam & 21 & $21 \mathrm{~km}$ & $18-24 ;$ & $\mathrm{AL}$ & $2.5 \mathrm{~kg}$ \\
et al. [28] & 12 & $56 \mathrm{~km}$ & $50-70 ;$ & & $1.4 \mathrm{~kg}$ \\
& & & WS $1.8-7.2$ &
\end{tabular}

WS $1.8-7.2$

\begin{tabular}{llllll}
\hline $\begin{array}{l}\text { Nolte } \\
\text { et al. [24] }\end{array}$ & 18 & $25 \mathrm{~km}$ & $\begin{array}{l}34.9-44.3 ; \\
15-28\end{array}$ & AL & $3.8 \%$ \\
& & &
\end{tabular}

Marathon finishing time was inversely related to \% BW loss during the race. $55 \%$ of finishers lost more than $2 \% \mathrm{BW}$. Runners finishing in less than 180 min lost $>3 \%$ BW kg BW loss

Euhydration (unchanged TBW) was maintained by AL drinking despite a $1-\mathrm{kg}(1.3 \%)$ BW loss

Slower finishers drank more

No change in TBW, plasma sodium concentration and plasma osmolality in the $21-\mathrm{km}$ race despite a $1.4-\mathrm{kg}$ BW loss. Plasma sodium concentration was unchanged in the $56-\mathrm{km}$ Plasma osmolality was increased and TBW fell by $1.4 \mathrm{~kg}$

TBW fell by $2 \%$ during exercise. The reduction in TBW was Serum sodium concentration less than that in BW and plasma osmolality did not change during exercise. Core body temperatures were not abnormally elevated after exercise
Despite a 1.4-kg BW loss in the $21-\mathrm{km}$ race, TBW did not change significantly. In the $56-\mathrm{km}$ race, the reduction in BW $(2.5 \mathrm{~kg})$ was greater than the fall in TBW $(1.4 \mathrm{~kg})$ race despite a 2.5 -kg loss of BW.

\footnotetext{
$\mathrm{AL}=$ Ad libitum fluid intake; $\mathrm{CE}=$ cycle ergometer exercise; $\mathrm{ECW}=$ extracellular water; $\mathrm{FF}=\mathrm{fluid}>\mathrm{sweat}$ losses; $\mathrm{LF}=$ little fluid $(<\mathrm{AL}) ; \mathrm{MR}=\mathrm{mouth}$ rinsing only; $\mathrm{NF}=$ no fluid; $\mathrm{PR}=$ performance ride or run; $\mathrm{RH}=$ relative humidity; $\mathrm{SF}=$ some fluid $(>\mathrm{NF},<\mathrm{FF}) ; \mathrm{TM}=$ treadmill $\mathrm{run} ; \mathrm{TBW}=$ total body water; WBGT = wet bulb globe temperature; WS = wind speed.
} 
tent of the weight loss. This explanation is compatible with the predictions of a complex model of exercise regulation [43-45].

If correct, this would explain why it is possible for elite athletes to perform well while drinking sparingly during exercise, for the fastest marathon $[36,41]$ and ultramarathon runners $[37,40]$ to be amongst the most dehydrated runners in those races, and for athletes who have lost in excess of $10 \%$ of $\mathrm{BW}$ to be amongst the top finishers in 226-km Ironman triathlons [38].

\section{Drinking Behaviors of Real Athletes in Real Competitions}

If we wish to force all athletes to drink according to a singular doctrine, then perhaps we need first to determine what they actually do in real competitions. In our study published more than 2 decades ago [13], we found that the majority of athletes drink about $500 \mathrm{ml} / \mathrm{h}$ and all lose some weight during exercise since this rate of fluid ingestion is less than the rate of sweat and other losses. This information influenced the evolution of the drinking guidelines that I developed for the International Marathon Medical Directors Association in 2003 [46] and which promoted drinking according to the dictates of thirst and not in excess of about $800 \mathrm{ml} / \mathrm{h}$. The advice contained in the most recent 2007 ACSM guidelines [5, 6 ] is now more similar.

More recently, we plotted the range of BW changes that occur in athletes completing a $224-\mathrm{km}$ Ironman triathlon (fig. 1). All entrants in this race received the same drinking advice - drink according to the dictates of thirst and not in excess of $800 \mathrm{ml} / \mathrm{h}$. In addition, the availability of fluid on the course was restricted, in keeping with the finding of Speedy et al. [47] that such fluid restriction is necessary to reduce the incidence of EAH and EAHE.

The remarkable finding was that despite all receiving the same advice, BW changes in athletes in that race ranged from a gain of $3 \%$ to a loss of $13 \%$ with the commonest weight loss being $3 \%$. Even in a much shorter $42-$ $\mathrm{km}$ marathon [41], BW changes ranged from a gain of 5\% to a loss of $9 \%$.

It is clear that the factors determining drinking behavior during competitive exercise are poorly understood. Perhaps we should study this phenomenon more carefully before we produce dogmatic guidelines that conflict with common sense, the scientific evidence and even what athletes actually do during exercise and competition.

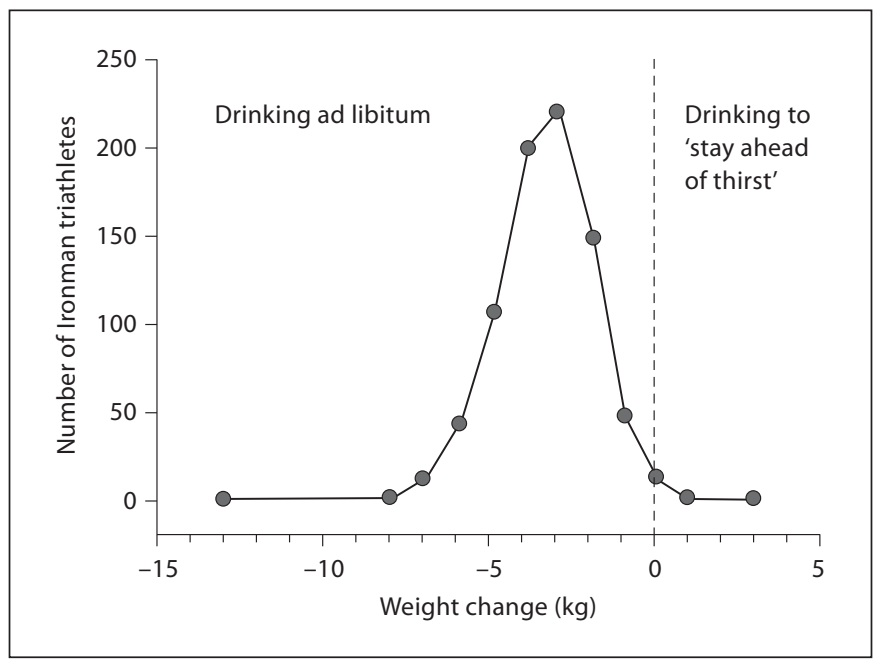

Fig. 1. The distribution of BW losses in athletes completing the 2000 and 2001 South African Ironman Triathlons [38].

\section{Conclusion}

There is no published scientific evidence to show that drinking beyond the dictates of thirst - that is drinking 'to stay ahead of thirst' during exercise - produces a more beneficial outcome than does drinking according to the dictates of thirst. Since the very best athletes often develop the greatest $\mathrm{BW}$ losses during competitive exercise, the possibility is that drinking sparingly during exercise is ergogenic whereas drinking 'to stay ahead of thirst' may even impair exercise performance in some cases. However, it is clear that ad libitum drinking is less likely to cause EAH and EAHE in predisposed individuals [48].

While we await more studies which compare the relative biological effects of drinking either ad libitum or to 'stay ahead of thirst', those advising athletes can safely be assured that the balance of the current evidence supports the conclusion that drinking to thirst is the optimum drinking behavior during exercise (table 1).

\section{Disclosure Statement}

From 1982 to 2008 the author's research on fluids and exercise was funded, in part, by G.W. Leppin (Pty) (Ltd.) and Bromor Foods. The author currently receives no research funding from the sports drink industry. 


\section{References}

1 Noakes TD: Lore of Running. Champaign, Human Kinetics Publishers, 2003.

$\checkmark 2$ American College of Sports Medicine: Position stand on the prevention of thermal injuries during distance running. Med Sci Sports Exerc 1987;19:529-533.

3 Convertino VA, Armstrong LE, Coyle EF, Mack GW, Sawka MN, Senay LC Jr, Sherman WM: American College of Sports Medicine position stand. Exercise and fluid replacement. Med Sci Sports Exer 1996;28:i-vii.

4 Armstrong LE, Epstein Y, Greenleaf JE, Haymes EM, Hubbard RW, Roberts WO, Thompson PD: American College of Sports Medicine position stand. Heat and cold illnesses during distance running. Med Sci Sports Exer 1996;28:i-X.

5 Armstrong LE, Casa DJ, Millard-Stafford M, Moran DS, Pyne SW, Roberts WO: American College of Sports Medicine position stand. Exertional heat illness during training and competition. Med Sci Sports Exerc 2007;39:556-572.

-6 Sawka MN, Burke LM, Eichner ER, Maughan RJ, Montain SJ, Stachenfeld NS: American College of Sports Medicine position stand. Exercise and fluid replacement. Med Sci Sports Exerc 2007;39:377-390.

7 Matheson GO: The journal's role in helping change medical practice. Phys Sportsmed 2001;29:5.

8 Hadgraft R: Tea with Mr Newton. 100,000 Miles. The Longest Protest March in History. Essex, Desert Island Books, 2009.

-9 Cade R, Spooner G, Schlein E, Pickering M, Dean R: Effect of fluid, electrolyte, and glucose replacement during exercise on performance, body temperature, rate of sweat loss, and compositional changes of extracellular fluid. J Sports Med Phys Fitness 1972;12: $150-156$.

10 Cade JR, Free HJ, De Quesada AM, Shires DL, Roby L: Changes in body fluid composition and volume during vigorous exercise by athletes. J Sports Med Phys Fitness 1971;11: 172-178.

11 Wyndham CH, Strydom NB: The danger of an inadequate water intake during marathon running. S Afr Med J 1969;43:893-896.

$\checkmark 12$ Ladell WS: Effects on man of restricted water supply. Br Med Bull 1947;5:9-13.

-13 Noakes TD, Adams BA, Myburgh KH, Greeff C, Lotz T, Nathan M: The danger of an inadequate water intake during prolonged exercise. A novel concept re-visited. Eur J Appl Physiol Occup Physiol 1988;57: 210-219.

14 Kerstein M, Mager M, Hubbard R, Connelly $\mathrm{J}$ : Heat-related problems in the desert: the environment can be an enemy. Mil Med 1984; 149:650-656

15 Montain SJ, Latzka WA, Sawka MN: Fluid replacement recommendations for training in hot weather. Mil Med 1999;164:502-508.
16 American College of Sports Medicine: The American College of Sports Medicine position statement on prevention of heat injuries during distance running. Med Sci Sports 1975;7:vii-vix.

17 Wang AT, McCoy CP, Murad MH, Montori VM: Association between industry affiliation and position on cardiovascular risk with rosiglitazone: cross sectional systematic review. BMJ 2010;340:c1344.

18 Bakan J: The Corporation: The Pathological Pursuit of Profit and Power. New York, Free Press, 2004.

19 Noakes TD: Can we trust rehydration research?; in McNamee M (ed): Philosophy and Sciences of Exercise, Sports and Health. Abingdon, Taylor \& Francis Books, 2004, pp 144-168.

20 Noakes TD: Overconsumption of fluids by athletes. BMJ 2003;327:113-114.

21 Noakes TD: Changes in body mass alone explain almost all of the variance in the serum sodium concentrations during prolonged exercise. Has commercial influence impeded scientific endeavour? Br J Sports Med, Online first: 22nd December 2010

22 Noakes TD: Hydration in the marathon: using thirst to gauge safe fluid replacement. Sports Med 2007;37:463-466.

23 Noakes TD: Drinking guidelines for exercise: what evidence is there that athletes should drink 'as much as tolerable', 'to replace the weight lost during exercise' or 'ad libitum'? J Sports Sci 2007;25:781-796.

24 Nolte H, Noakes TD, Van Vuuren B: Appropriately trained humans can safely perform vigorous, competitive self-paced exercise in extreme heat $\left(44^{\circ} \mathrm{C}\right)$ when drinking water ad libitum. J Sports Sci (in review).

25 Nolte H, Noakes TD, Van Vuuren B: Ad libitum fluid replacement in military personnel during a $4 \mathrm{~h}$ route march. Med Sci Sports Exerc 2010;42:1675-1680.

26 Nolte H, Noakes TD, Van Vuuren B: Protection of total body water content and absence of hyperthermia despite $2 \%$ body mass loss ('voluntary dehydration') in soldiers drinking ad libitum during prolonged exercise in cool environmental conditions. Br J Sports Med, in press.

27 Tam N, Hew-Butler T, Papadopoulou E, Nolte H, Noakes TD: Fluid intake and changes in blood biochemistry, running speed and body mass during an $80 \mathrm{~km}$ mountain trail race. Med Sport 2009;13:108-115.

28 Tam N, Nolte H, Noakes TD: Changes in total body water during a running race of 21.1 $\mathrm{km}$ and $56 \mathrm{~km}$ in athletes drinking ad libitum. Clin J Sport Med, in press.

29 Costill DL, Kammer WF, Fisher A: Fluid ingestion during distance running. Arch Environ Health 1970;21:520-525.
30 Robinson TA, Hawley JA, Palmer GS, Wilson GR, Gray DA, Noakes TD, Dennis SC: Water ingestion does not improve 1-h cycling performance in moderate ambient temperatures. Eur J Appl Physiol Occup Physiol 1995;71:153-160.

31 Daries HN, Noakes TD, Dennis SC: Effect of fluid intake volume on 2-h running performances in a 25 degrees $\mathrm{C}$ environment. Med Sci Sports Exerc 2000;32:1783-1789.

32 Dugas JP, Oosthuizen U, Tucker R, Noakes TD: Rates of fluid ingestion alter pacing but not thermoregulatory responses during prolonged exercise in hot and humid conditions with appropriate convective cooling. Eur J Appl Physiol 2009;105:69-80.

33 Rose S, Peters-Futre EM: Ad libitum adjustments to fluid intake during cool environmental conditions maintain hydration status during a 3-day mountain bike race. $\mathrm{Br} \mathrm{J}$ Sports Med 2010;44:430-436.

34 Schenk K, Gatterer H, Ferrari M, Ferrari P, Cascio VL, Burtscher M: Bike Transalp 2008: liquid intake and its effect on the body's fluid homeostasis in the course of a multistage, cross-country, MTB marathon race in the central Alps. Clin J Sport Med 2010;20:47-52.

-35 Refsum HE, Tveit B, Meen HD, Stromme SB: Serum electrolyte, fluid and acid-base balance after prolonged heavy exercise at low environmental temperature. Scand J Clin Lab Invest 1973;32:117-122.

36 Cheuvront SN, Haymes EM: Thermoregulation and marathon running: biological and environmental influences. Sports Med 2001; 31:743-762.

-37 Kao WF, Shyu CL, Yang XW, Hsu TF, Chen JJ, Kao WC, Polun C, Huang YJ, Kuo FC, Huang CI, Lee CH: Athletic performance and serial weight changes during 12 - and 24 hour ultra-marathons. Clin J Sport Med 2008;18:155-158.

- 38 Sharwood KA, Collins M, Goedecke JH, Wilson G, Noakes TD: Weight changes, medical complications, and performance during an Ironman triathlon. Br J Sports Med 2004;38:718-724.

-39 Sharwood K, Collins M, Goedecke J, Wilson G, Noakes TD: Weight changes, sodium levels, and performance in the South African Ironman Triathlon. Clin J Sport Med 2002; 12:391-399.

40 Zouhal H, Groussard C, Vincent S, Jacob C, Abderrahman AB, Delamarche P, GratasDelamarche A: Athletic performance and weight changes during the 'Marathon of Sands' in athletes well-trained in endurance. Int J Sports Med 2009;30:516-521.

41 Zouhal H, Groussard C, Minter G, Vincent S, Gratas-Delamarche A, Delamarche P, Noakes TD: Inverse relationship between \% weight change and finishing time in 643 42$\mathrm{km}$ marathon runners. Br J Sports Med, in press. 
42 Sawka MN, Noakes TD: Does dehydration impair exercise performance? Med Sci Sports Exerc 2007;39:1209-1217.

$>43$ Noakes TD, St Clair Gibson A, Lambert EV: From catastrophe to complexity: a novel model of integrative central neural regulation of effort and fatigue during exercise in humans. Br J Sports Med 2004;38:511-514.

-44 St Clair Gibson A, Noakes TD: Evidence for complex system integration and dynamic neural regulation of skeletal muscle recruitment during exercise in humans. Br J Sports Med 2004;38:797-806.

$\checkmark 45$ Noakes TD, St Clair Gibson A, Lambert EV: From catastrophe to complexity: a novel model of integrative central neural regulation of effort and fatigue during exercise in humans: summary and conclusions. $\mathrm{Br} \mathrm{J}$ Sports Med 2005;39:120-124.

-46 Noakes TD: Fluid replacement during marathon running. Clin J Sport Med 2003;13: 309-318.
47 Speedy DB, Rogers IR, Noakes TD, Thompson JM, Guirey J, Safih S, Boswell DR: Diagnosis and prevention of hyponatremia at an ultradistance triathlon. Clin J Sport Med 2000;10:52-58.

48 Noakes TD, Sharwood K, Speedy D, Hew T, Reid S, Dugas J, Almond C, Wharam P, Weschler L: Three independent biological mechanisms cause exercise-associated hyponatremia: evidence from 2,135 weighed competitive athletic performances. Proc Natl Acad Sci USA 2005;102:18550-18555.

- 49 Below PR, Mora-Rodriguez R, GonzalezAlonso J, Coyle EF: Fluid and carbohydrate ingestion independently improve performance during $1 \mathrm{~h}$ of intense exercise. Med Sci Sports Exerc 1995;27:200-210.

50 McConell GK, Burge CM, Skinner SL, Hargreaves M: Influence of ingested fluid volume on physiological responses during prolonged exercise. Acta Physiol Scand 1997; 160:149-156.
51 McConell GK, Stephens TJ, Canny BJ: Fluid ingestion does not influence intense 1-h exercise performance in a mild environment. Med Sci Sports Exerc 1998;386-392.

52 Backx K, van Someren KA, Palmer GS: One hour cycling performance is not affected by ingested fluid volume. Int J Sport Nutr Exerc Metab 2003;13:333-342.

53 Saunders AG, Dugas JP, Tucker R, Lambert MI, Noakes TD: The effects of different air velocities on heat storage and body temperature in humans cycling in a hot, humid environment. Acta Physiol Scand 2005;183:241255.

54 Fudge BW, Easton C, Kingsmore D, Kiplamai FK, Onywera VO, Westerterp KR, Kayser B, Noakes TD, Pitsiladis YP: Elite Kenyan endurance runners are hydrated day-to-day with ad libitum fluid intake. Med Sci Sports Exerc 2008;40:1171-1179. 